Abstracta Iranica Abstracta Iranica

Revue bibliographique pour le domaine irano-aryen

Volume 31 | 2011

Comptes rendus des publications de 2008

\title{
«The Baha'is and the Constitutional Revolution: The Case of Sari, Mazandaran, 1906-1913 ». Iranian Studies, 41/3, 2008, p. 343-363.
}

\section{Denis Hermann}

\section{(2) OpenEdition}

1 Journals

\section{Édition électronique}

URL : http://journals.openedition.org/abstractairanica/39602

DOI : 10.4000/abstractairanica.39602

ISSN : 1961-960X

Éditeur :

CNRS (UMR 7528 Mondes iraniens et indiens), Éditions de l'IFRI

\section{Édition imprimée}

Date de publication : 15 mai 2011

ISSN : 0240-8910

\section{Référence électronique}

Denis Hermann, « « The Baha'is and the Constitutional Revolution: The Case of Sari, Mazandaran, 1906-1913 ». Iranian Studies, 41/3, 2008, p. 343-363. », Abstracta Iranica [En ligne], Volume 31 | 2011, document 180, mis en ligne le 11 octobre 2012, consulté le 05 octobre 2020. URL : http:// journals.openedition.org/abstractairanica/39602; DOI : https://doi.org/10.4000/abstractairanica 39602

Ce document a été généré automatiquement le 5 octobre 2020.

Tous droits réservés 


\section{«The Baha'is and the Constitutional Revolution: The Case of Sari, Mazandaran, 1906-1913 ». Iranian Studies, 41/3, 2008, p. 343-363.}

Denis Hermann

1 L'article se veut autant une analyse du rôle des bahaïs de Sārī au sein du mouvement constitutionnel qu'une critique du manque d'intérêt présupposé pour le bahaïsme des chercheurs travaillant sur cette période. Il existe pourtant déjà de nombreuses études revenant sur le rôle réel ou supposé des bahaïs au cours du mouvement constitutionnel. Certains ont même cru voir dans les idéaux socio-démocrates du mouvement constitutionnel une influence déterminante du bahaïsme et/ou de l'azalisme. Ces dernières thèses ont cependant été remises en question par Sohrāb Yazdānī, à mon sens de manière convaincante (voir c.r. n²20, Abs. Ir., 28 (2005)).

2 Après une description détaillée de la formation de la communauté bahaïe de Sārī - la capitale du Māzandarān - dans la seconde moitié du XIX', l'A. revient sur le rôle politique central des responsables de la communauté dans l'évolution du mouvement constitutionnel dans la ville et la région. Moojan Momen souligne à ce titre deux éléments importants :

3 1) Il apparait que le fondateur de l'anjoman pro-constitutionnaliste de la ville, l'anjoman$e$ haqiqaat, était un membre influent de la communauté bahaïe de Sārī. Cet anjuman fut créé pour s'opposer en premier lieu à l'anjoman anti-constitutionnaliste, l'anjoman-e sa'ādat, dominé par les oulémas de la ville soutenant ŠeyH Faḍl Allāh Nūrī (m. 1909).

4 2) Les bahaïs étaient sur-représentés dans l'anjoman-e haqiqat et jouèrent un rôle pionnier dans la fondation de la première école « moderne » de Sārī, la Sālāriyye.

5 Ainsi, plus qu'ailleurs certainement, les bahaïs de la ville jouèrent un rôle important dans le soutien au mouvement constitutionnel. Cependant, cela ne démontre pas que 
les bahaïs et la pensée bahaïe jouèrent un rôle central dans le mouvement constitutionnel pris dans son ensemble.

6 L'un des intérêts de l'article provient cependant de cet éclairage sur les événements à Sārī et au Māzandarān au cours du mouvement constitutionnel, même s'il essentiellement réalisé à travers le prisme du bahaïsme. Cette région a encore été très peu étudiée, car éclipsée peut-être par l'intérêt suscité par Rašt et le Gīlān. L'A. souligne ainsi les luttes d'influence entre factions pro et anti-constitutionnalistes qui se disputèrent régulièrement le soutien de la tribu 'Abd al-Malek, l'une des forces armées du Māzandarān. Il revient ainsi sur la vague de répression que subirent les proconstitutionnalistes de Sārī et du Māzandarān au cours de l'été 1911, lorsque le souverain déchu, Moḥammad 'Alī Šāh (m. 1925), arriva à Gorgān avec le soutien des russes dans l'objectif de reconquérir le pouvoir.

INDEX

Thèmes : 4.3. Histoire de l'Iran moderne (à partir de 1905)

\section{AUTEURS}

\section{DENIS HERMANN}

CNRS - Mondes iranien et indien - Paris 